\begin{tabular}{|c|c|c|}
\hline Beitr. Ent. & Keltern & ISSN 0005-805X \\
\hline $\mathbf{5 7}(2007) 2$ & S. $397-400$ & 21.12 .2007 \\
\hline
\end{tabular}

\title{
First record of a Dung Midge from the South Atlantic island group of Tristan da Cunha
}

\section{(Diptera: Scatopsidae)}

With 1 plate

Christine Hänel and Jean-Paul Haenni

\section{Summary}

Scatopsidae Dung Midges have not been known to occur within the south Atlantic island group of Tristan da Cunha. The finding in 2005 of Scatopse notata (Linnaeus, 1758) at Nightingale Island marks the occurrence of a member from that family at the archipelago for the first time. As such, it also documents the species presence in the Afrotropical region for which no previous records are known. Here we report on the finding of $S$. notata at Nightingale Island, and put forward the scenarios under which its arrival may have occurred.

\section{Zusammenfassung}

Das Vorkommen von Dungmücken (Scatopsidae) auf Inseln der Gruppe Tristan da Cunha im Südatlantik war bisher unbekannt. 2005 wurde Scatopse notata (Linnaeus, 1758) auf der Insel Nightingale gefunden. Das ist der erste Nachweis der Familie auf dem Archipel. Weiterhin ist das auch die erste Meldung dieser Art aus der Afrotropischen Region. In dieser Arbeit informieren wir über das Auffinden von S. notata auf der Insel Nightingale und diskutieren, wie diese Mücke auf die Insel gekommen sein mag.

Key words

Diptera, Scatopsidae, Scatopse, Dung Midge, fly, Tristan da Cunha, Nightingale Island, South Atlantic, introduction.

\section{Introduction}

Nightingale Island lies in the South Atlantic at $37^{\circ} 25^{\prime} \mathrm{S}, 12^{\circ} 29^{\prime} \mathrm{W}$, approximately $34-38 \mathrm{~km}$ SSW of Tristan da Cunha [TdC]. It has an area of $\pm 4 \mathrm{~km}^{2}$ and is the smallest of the four principal islands that comprise the $\mathrm{TdC}$ archipelago (see description with locality map in Beiträge zur Entomology 57 [1]: 105-106). Nightingale is known for its seabirds, in particular the Great Shearwaters Puffinus gravis (O'ReILly, 1818), which when breeding are most abundant at this Island. A number of vagrant birds have also been recorded. There is no permanent human settlement on Nightingale, but the Island is visited regularly. Since early 1800 when Tristanians first settled at TdC, the birds have been of prime interest and reason for going to Nightingale. Access by Tristanians to that island is not restricted, but visitors from vessels of foreign destinations are required to comply with $\mathrm{TdC}$ regulations and can spend up to a day ashore in the company of a local guide. 
The invertebrate fauna of Nightingale has only been poorly studied. At least 100 species of the approximately 430 recorded from the TdC archipelago (HäNEL, 2007) are known to occur at Nightingale of which more than half are indigenous $(20+$ native and $30+$ endemic). The Diptera form the most prominent group. Within the archipelago at least 66 species have been recorded (Hänel, 2007) of which two dozen occur at Nightingale. At the latter, approximately half of the flies known are endemics, while in the former the endemic components makes up about a third of the flies so far recorded.

In an attempt to fill some of the gaps about the invertebrate knowledge relating to the less well studied northern islands of the archipelago, in particular Nightingale, a brief invertebrate project was conducted in 2005 as part of a larger program "Empowering the people of Tristan da Cunha to implement the CBD" (HäNEL, 2005). An insect collection was made at TdC and Nightingale Island, including flies. In this paper we report on the first finding of a Scatopsidae at the TdC archipelago, being Scatopse notata (LinnaEus, 1758) from Nightingale Island.

\section{Methods and results}

Fieldwork was conducted at TdC and Nightingale islands between February and April 2005. The majority of time was allocated to $\mathrm{TdC}$ and a period of two weeks was spent at Nightingale. Sampling was random, but focused on covering the major habitat types represented. The principal methods employed included Malaise trapping; sweep netting, hand searches and Tulgren extractions.

In total eight Scatopsidae specimens were collected (three females and five males) all identified as $S$. notata. They were caught at Nightingale between 26 March - 04 April 2005 by means of a Malaise trap at three localities. Two of the sites were on the coastal fringe (Viz. the East and West Landing areas) seasonally used by Subantarctic Fur Seals Arctocephalus tropicalis (GraY, 1872), Northern Rockhopper Penguins Eudyptes moseleyi Mathews \& Iredale, 1921 and visiting humans, and one site was in the upper reaches at a wetland area known as The Second Pond ( $\pm 200 \mathrm{~m}$ a.s.l.) used principally by Atlantic Yellow-nosed Albatross Thalassarche chlororhynchos (GMELIN, 1789). The specimens were preserved in $70 \%$ ethanol and later identified by J.-P.H. Two voucher specimens (one male and one female) were lodged in the collection of the Muséum d'histoire naturelle, Neuchâtel (MHNN), Switzerland. The remaining material is held in the Natural Resources Department on Tristan da Cunha.

\section{Discussion}

The Scatopsidae are a medium-sized but still inadequately known family of derived nematocerous Diptera, commonly referred to as Dung Midges (or Minute Black Scavenger Flies). Scatopse notata (Linnaeus, 1758) belongs to the few better known species of Scatopsidae. Probably of Palaearctic origin, $S$. notata is widespread in temperate regions and the Holarctic and is also present in South America (Chile), Australia (NSW, Victoria, ACT) and in New Zealand (Cook, 1957). However, it has so far not been recorded from the Afrotropical region as a whole. The larvae are saprophagous and live in a wide variety of decaying organic matter (e. g. rotten plant or vegetables remains, fungi, and the faeces of birds and mammals) and may occur under natural or anthropogenic conditions (Haenni \& Vaillant, 1994). The dark brown to black adults have a sausage-like body that averages $4-5 \mathrm{~mm}$ in length. The wings are similarly oblong with characteristic radial veins on the anterior edge that are distinctly darker and thicker than the less visible others and form what resembles a set of prominent parallelogram-like cells (Figure 1A). The male and female genital characters are important in enabling safe identifications (Figure 1B). 
The fact that $S$. notata is not a strong flyer means that its arrival at the remote archipelago was almost certainly facilitated. This could have been via artificially induced bridges (e. g. ships), or natural pathways (e. g. birds). In neither case can the origin of the species be speculated on with any certainty. The chances of natural immigration seem slim, considering that no Scatopsidae have been found at any of the other islands in the group, especially the larger Gough and TdC, whose insect fauna has been relatively well documented (Jones et al., 2003; HoldGaTe, 1965). The possibility of an accidental introduction by a bird should however not be disregarded. The only unnatural way by which the islands can be accessed is via ships and boats. In this regard traffic has increased considerably. Most passages occur between Cape Town, South Africa and TdC; a corridor in which $S$. notata is not known to occur, and quarantine measures are applied. The other traffic hails mainly from non-African ports and principally involves a limited quota of fishing vessels and a growing number of tourist ships. In the case of the former, landing is restricted en-route and at the archipelago to $\mathrm{TdC}$. In the case of the latter, landing destinations are poly-possible, both en route and within the $\mathrm{TdC}$ group where Nightingale and Inaccessible islands are the favoured targets for on-land wildlife experiences. The latter bridge provides a most likely scenario for $S$. notata's introduction, which in turn may account for the arrival route of some of the other non-native invertebrate species that have come to the fore from the 2005 collection (Reynolds \& Hänel, 2005; Hänel \& Disney, 2006; Schmelz \& Hänel, in press).
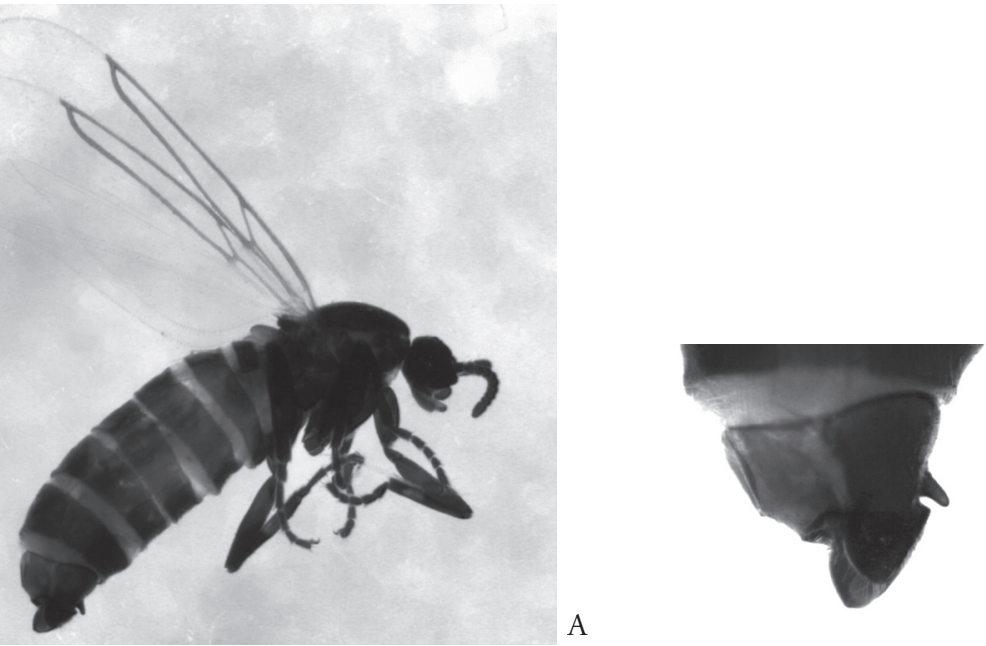

Fig. 1: Scatopse notata specimen from Nightingale Island. - A. Lateral view of a male. - B. The genitalia of a male in lateral view. Photos: (C) Jean-Paul Haenni.

\section{Acknowledgements}

C. H. thanks the Tristan authorities and James Glass (Agriculture \& Natural Resources Department) for entrusting the specimens to her for post project pursuit, and Ashley Kirk-Spriggs (Albany Museum, Grahamstown) for identifying the Diptera collection to family level. The 2005 invertebrate fieldwork at Tristan and Nightingale Islands was funded by the UK Government's Darwin Initiative and implemented by the Royal Society for the Protection of Birds, the UK Partner of BirdLife International \& the Tristan Island Government. 


\section{References}

Соoк, E. F. 1957: A contribution towards a monograph of the Scatopsidae (Diptera). Part VI, the genera Scatopse Geoffroy and Holoplagia Enderlein. - Annals of the Entomological Society America 49 (1956): 593-611.

Haenni J.-P. \& Vaillant, F. 1994: Description of dendrolimnobiontic larvae of Scatopsidae (Diptera) with a review of our knowledge of the preimaginal stages of the family. - Mitteilungen der Schweizerischen Entomologischen Gesellschaft 67: 43-59.

Hänel, C. 2005: Tristan da Cunha Invertebrate Project Report. - Royal Society for Protection of Birds, Sandy, United Kingdom. Internal manuscript: $70 \mathrm{pp}$.

HäNEL, C. 2007: Terrestrial invertebrates. - In: Ryan, P. 2007 (ed.): Field guide to the animals and plants of Tristan da Cunha and Gough Island. - Pisces Publications, Newbury for the Tristan Island Government: 110-119, 22 plates.

Hänel, C. \& Disney, R. H. L. 2006: Phoridae (Diptera) from Nightingale Island, South Atlantic. Entomologists Monthly Magazine 142: 127-128.

Holdgate, M. W. 1965: The biological report of the Royal Society expedition to Tristan da Cunha, 1962. Part III. The fauna of the Tristan da Cunha Islands. - Philosophical Transactions of the Royal Society London (Series B) 249: 361-402.

Jones, A. G.; Chown, S. L.; Webв, T. J. \& Gaston, K. J. 2003: The free-living pterygote insects of Gough Island, South Atlantic Ocean. - Systematics and Biodiversity 1 (2): 213-273.

ReYnolds, J. W. \& Hänel, C. 2005: The earthworms (Oligochaeta: Lumbricidae) of Tristan da Cunha and Nightingale Islands, South Atlantic Ocean. - Megadrilogica 19 (7): 47-56.

Schmelz, R. M. \& HäNel, C. (in press): On a collection of Enchytraeidae and Naididae from the Tristan da Cunha Islands, South Atlantic Ocean. - Folia Facultatis scientiarum naturalium Universitatis Masarykianae Brunensis.

\section{Author's addresses:}

Christine Hänel

P. O. Box 829

Stellenbosch 7599

South Africa

e-mail: chrishanel@yahoo.com
Subject editor:

Jean-Paul Haenni

Dr. F. MenZel
Muséum d'histoire naturelle

Rue des Terreaux

14 CH - 2000 Neuchâtel

Switzerland

e-mail: jean-paul.haenni@unine.ch 